\title{
The Weight of Health Expenditures on Household Income in Cameroon ${ }^{\dagger}$
}

\author{
Joseph Parfait OWOUNDI ${ }^{1, *}$ \\ ${ }^{1}$ Ministry of Economy, Planning and Regional Development, Cameroun
}

Received 15 October 2013; Accepted 25 October 2013

Editor: Paulo Canas Rodrigues

\begin{abstract}
African leaders pledged at the Abuja conference in 2001, to mobilize more financial resources to allocate at least $15 \%$ of their national budgets to the health sector to achieve the Millennium Development Goals (MDGs), seem to have difficulty meeting this commitment because of weakness and fragmentation of health systems. These commitments were renewed in Gaborone, Botswana in 2005 and in Ouagadougou, Burkina Faso in 2006. Indeed, donor funding is still a large part of public health spending on the continent. In some countries, $50 \%$ or more of their budgets come from foreign or private assistance. In about half the countries, the private health financing is equal to or exceeds largely public funding, up to $70 \%$ in some states like Sudan, Côte d'Ivoire, Cameroon, Chad, Liberia and Uganda. Only five countries (Rwanda, Malawi, Zambia, Burkina Faso, and Togo) have so far respected the promise made to the Abuja conference. In Cameroon, where $51 \%$ of the population lives on less than two dollars per day, the average propensity of the total medical consumption is very high. Indeed, $32 \%$ of households spend less than half of income on health, while $16 \%$ of households spend more than half of the income and $52 \%$ spend more than the total income. This corresponds to a weight of $68 \%$ in health care spending.
\end{abstract}

Keywords Average Propensity of Total Medical consumption, Health Expenditures, Household Income

DOI: $10.19139 /$ soic.v2i1.30

\footnotetext{
$\dagger$ This paper was published as a scientific report, which was ever presented at 59th ISI World Statistics Congress, Hong Kong, 25-30 August 2013.

*Correspondence to: Ministry of Economy, Planning and Regional Development. Po Box.660, Yaoundé- Cameroun. Email: owoundijoseph@yahoo.fr
} 


\section{Introduction}

Sufficient funds to health are a fundamental issue. In many countries, health expenditures remain below the defined threshold for the provision of a series of basic health services. For poor countries, the challenge is to increase the funding available to provide the necessary services and ensure adequate quality of care* (treatment, prevention, rehabilitation and health promotion). For rich countries, the challenge is that health spending does not increase with the aging of the population (which has implications on revenue and expenditure) and increased costs as a result of progress technology (a challenge that also face some poorer countries).

The Bamako Initiative, adopted in 1988, has developed a strategy of community participation and cost recovery to promote primary health care. The actual membership of sub-Saharan Africa has been very progressive in the 90s. Cost recovery still the problem of affordability by the absence of a political risksharing coupled with geographic accessibility by lack of monitoring of health coverage. The price elasticity of demand excludes disadvantaged classes for which the indigent and support measures that accompany it are often remained at the project stage. The establishment of financing schemes guaranteeing the reduction of inequalities is limited by an economy based primarily on an informal basis (A. Richard, 2004).

According to a study by Adam Leive and Xu Ke in 2008, the system of financing health expenditure in Africa is too weak to protect households against catastrophic expenses. The borrowing or selling assets to finance health care is a common practice. The proportion of households who have paid their health spending by borrowing or selling assets ranged from $23 \%$ in Zambia to $68 \%$ in Burkina Faso.

\section{Socio-economic context}

The economic crisis of the 1980 years drove Cameroon into recession. Accentuated by the $60 \%$ decrease in salaries of civil servants in 1993 and the devaluation of the CFA franc in 1994, this crisis has significantly changed the structure of consumption and access to care. Thus, the decline in households' financial capacity was accompanied by a decline in the state budget devoted to health. The share of health expenditure in the household budget increased from

*These treatments refer to what WHO calls Universal Health Coverage, which is to ensure that the entire population has access to preventive, curative, rehabilitative and health promotion it needs and that these services be of sufficient quality to be effective, their cost without causing financial difficulties for users. Universal coverage has its roots in the WHO Constitution, adopted in 1948, which made health one of the fundamental rights of every human being, and the Global Strategy for Health for All, launched in 1979 (www . who.int). 
4\% in 1984 to $6 \%$ in 1996 and $7.2 \%$ in 2001. Between 1995 and 1996, total health expenditure was 250 billion CFA francs, $72 \%$ financed by households, $22 \%$ by the state and 6\% partners (Commeyras et al., 2005). Graphic 1 below shows the evolution of the national expenditure on health as percentage of GDP.

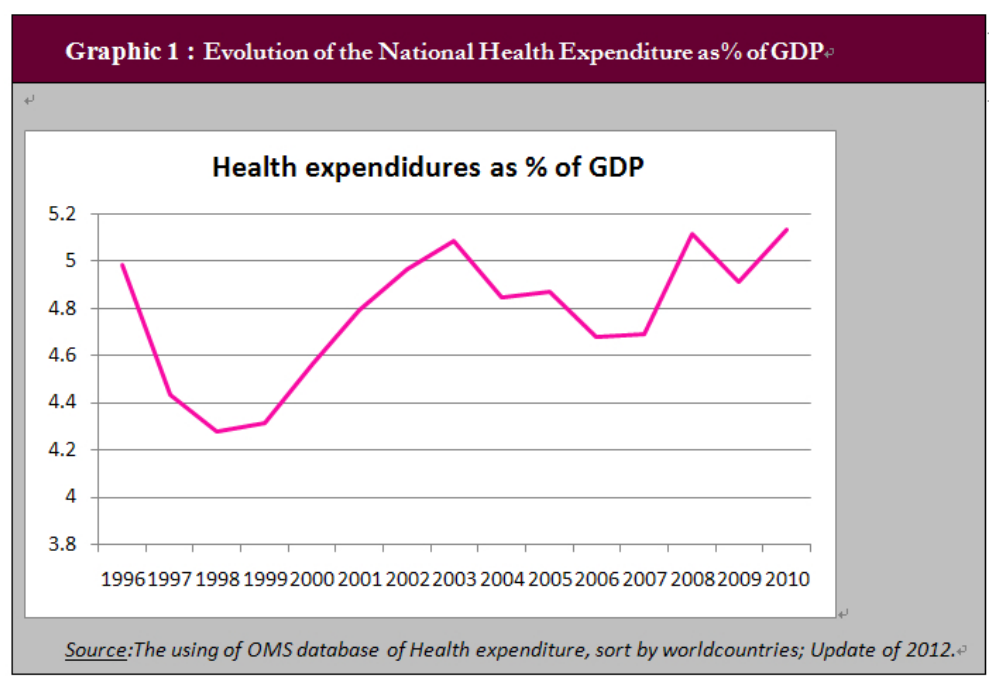

In 1982, Cameroon has adopted and implemented the primary health care (health for all by the year 2000) to provide free care. In 1993, the country adopted the Bamako Initiative through policy reorientation of primary health care, through: the recovery of costs for care and medications, community participation, and the organization of health districts (Sieleunou et al., 2010). In addition, Cameroon has benefited from innovative financing of health after numerous international initiatives aimed at achieving the Millennium Development Goals (MDGs) by 2015. The Health Sector Wide Approach (SWAP), adopted in 2010, emerges as a key instrument for mobilizing and optimizing the use of resources for the implementation of the Health Sector Strategy. Despite these measures, the "Average Propensity of Total Medical Consumption" of households is high in Cameroon, where $51 \%$ of the population lives on less than two dollars a day.

The objective of this study is to provide some answers about the relationship between "Population and Health" through the analysis of the weight of health expenditure on household income. Thus, this study aimed to answer some specific to the situation in Cameroon questions, including: What is the impact of health expenditures on household income? What is the share of household income devoted to health care spending? What is the "average propensity of the total medical consumption"? What is the profile of households which bear the brunt of health spending? To this end, we have structured our work in five parties, 
namely: (i) introduction, (ii) general information on health expenditures in Africa, (ii) the inequality of income distribution in Cameroon (iii) methodology, (iv) data analysis, and (iv) the conclusion and recommendations.

\section{Definition of concepts}

\section{Health Expenditures}

As defined by the World Bank, the total health expenditure is the sum of expenditures on public and private health. It covers the provision of health services (preventive and curative), family planning activities, related to nutrition and reserved for emergency health assistance but excludes the provision of water services and hygiene.

Health expenditure, recorded in the accounts of health, covering different types of services: hospital charges, costs "outpatient" drug spending, the expenditure approach, prostheses and small equipment medical, medical transportation costs (IRDES, 2013).

In this study, the health expenditure of households include expenses related to medical care and goods (hospital care, outpatient care, medical transportation and medical goods), as well as preventive medicine.

\section{Health financing}

According to WHO, health financing is the way financial resources are generated, allocated and used in health systems. The following issues relating to health financing, should be asked: how and from what sources raise sufficient funds for health? How to overcome financial barriers that exclude many poor accesses to health services? How to offer a range of services of fair and effective health?

\section{Household income}

In economics, the primary income (primary income) of household income that households derive from their contribution to economic activity either directly (income from employment or self-employment) or indirectly (income furniture placement or real estate). It does not include social security benefits - this is income before redistribution. In national accounts, the primary household income includes income directly or indirectly related to household participation in the production process (INSEE, 2013). In our study, the income mentioned here is imputed income to the main activity of household members.

\section{Average propensity of the total medical consumption}

The average propensity of medical consumption is the share of income spent on medical consumption. The total medical consumption includes the consumption of medical care and goods (CSBMs), as well as preventive medicine. It is hospital care, outpatient care, medical transportation and medical goods. 


\section{Weight of health expenditure}

At the individual level, the weight of health care costs can be considered as the relationship between health expenditure and income. But in order to define classes vulnerable and disadvantaged social groups to which measures should be taken to improve the quality of health care spending, we can define the weight of health expenditure as a proportion of households or persons that support health spending well over half of the household income.

\section{General information on health financing in Africa}

The key issue that arises in terms of health care spending is not how to reduce but rather how we choose to finance (issue of receipts) and optimized (question of the organization), with the goal of an inclusive health fair system. So, thinking about the financial aspects of expenditure and revenue of the health system cannot be achieved without addressing the problem of the organization of this system. Indeed, whether it is able to bring new resources to the system or to consider how spending facing the community versus individual, any direction that is acceptable only if the financial effort is fair and optimized what it will be used.

However, three fundamental developments appear to maintain "upstream" the dynamism of the expense. These are: (i) changes in health (epidemiology and aging) that shape the needs and demand for health care, (ii) the standard of living through the rise in demand for health care driven by a higher income, and (iii) the progress of medical knowledge (technical progress), allowing both to better diagnose diseases and better treatment (Albouy et al, 2009.). Thus, knowledge of the sheer scale of health spending by households is an avenue that should be explored, given the importance of private health expenditure in development planning.

African leaders pledged at the Abuja conference in 2001, to mobilize more financial resources for the achievement of the Millennium Development Goals (MDGs) by allocating at least $15 \%$ of their national budgets to the sector health, seem to have difficulty meeting their commitments, because of weakness and fragmentation of health systems. These commitments were renewed in Gaborone, Botswana in 2005 and in Ouagadougou, Burkina Faso in 2006. Indeed, donor funding is still a large part of public health spending on the continent. Thus, in some countries, $50 \%$ or more of their budgets come from the private or foreign aid, according to the 2013 WHO report on global health statistics (see table below).

In nearly half of the country is $40 \%$, the private health financing is equal to or exceeds largely public funding, up more than $70 \%$ (see Graph 1.2) in some states such as: Cameroon $(70,4 \%)$, the DRC (71.6\%), Sao Tome and principles $(64.7 \%)$, the Chad (75\%), Ivory Coast (75.5\%), the Guinea (67.5\%) to Bissau $(66.9 \%)$, Guinea, Liberia (81\%), Nigeria (68.5\%), Sierra Leone (84.7\%) in Burundi (65\%), 
Uganda (76.9\%), Sudan (72.4\%), Tanzania (60.8\%), Mauritius (62.9\%). The expenditure of social security against health are very low or non-existent in most of these countries.

Table 1. Health Expenditure in Central Africa.

\begin{tabular}{|c|c|c|c|c|c|c|c|c|c|c|c|c|}
\hline \multirow{3}{*}{$\begin{array}{l}\text { WHO } \\
\text { states } \\
\text { members }\end{array}$} & \multicolumn{12}{|c|}{ Ratios of health spending in Sub-Saharan Africa } \\
\hline & \multicolumn{2}{|c|}{$\begin{array}{l}\text { Global } \\
\text { health } \\
\text { expenditures } \\
\text { (GHE) } \\
\text { (as \% } \\
\text { of GDP) }\end{array}$} & \multicolumn{2}{|c|}{\begin{tabular}{|l|} 
Spending of \\
public heath \\
administrations \\
(PHA) \\
(as \% \\
of GHE)
\end{tabular}} & \multicolumn{2}{|c|}{$\begin{array}{l}\text { Private } \\
\text { health } \\
\text { expenditures } \\
\text { (as \% } \\
\text { of GHE) }\end{array}$} & \multicolumn{2}{|c|}{\begin{tabular}{|l|}
$\begin{array}{l}\text { Spending } \\
\text { of PHA }\end{array}$ \\
(as \% \\
of global \\
expenditure \\
of Public \\
Administration
\end{tabular}} & \multicolumn{2}{|c|}{$\begin{array}{l}\text { External } \\
\text { health } \\
\text { financing } \\
\text { (as \% } \\
\text { of GHE) }\end{array}$} & \multicolumn{2}{|c|}{$\begin{array}{l}\text { Social } \\
\text { security } \\
\text { health } \\
\text { spending } \\
\text { (as \% } \\
\text { of PHA) }\end{array}$} \\
\hline & 2000 & 2010 & 2000 & 2010 & 2000 & 2010 & 2000 & 2010 & 2000 & 2010 & 2000 & 2010 \\
\hline Cameroon & 4,4 & 5,1 & 19,3 & 29,6 & 80,7 & 70,4 & 5,5 & 8,5 & 4,3 & 7,0 & 4,2 & 2,6 \\
\hline Congo & 2,1 & 2,3 & 57,5 & 60,5 & 42,5 & 39,5 & 4,8 & 6,5 & 4,6 & 4,6 & 0 & 0 \\
\hline Gabon & 2,5 & 3,5 & 42,0 & 51,8 & 58,0 & 48,2 & 4,8 & 6,6 & 2,6 & 2,3 & 5,7 & 24,9 \\
\hline \begin{tabular}{|l} 
Guinée- \\
Equatorial
\end{tabular} & 1,9 & 4,2 & 46,3 & 57,4 & 53,7 & 42,6 & 7,8 & 7,0 & 8,8 & 2,1 & 0 & 0 \\
\hline $\begin{array}{l}\text { République } \\
\text { Centrafricain }\end{array}$ & 2,2 & 3,8 & 93,1 & 51,0 & 6,9 & 49,0 & 12,9 & 10,4 & 35,4 & 25,3 & .. & . \\
\hline RDC & 4,7 & 7,5 & 4,2 & 28,4 & 95,8 & 71,6 & 1,8 & 10,0 & 2,8 & 33,0 & $\ldots$ & \\
\hline $\begin{array}{l}\text { Sao Tomé et } \\
\text { Principes }\end{array}$ & 8,4 & 7,5 & 43,2 & 35,3 & 56,8 & 64,7 & 9,0 & 5,6 & 34,8 & 20,3 & 0 & 0 \\
\hline Tchad & 6,3 & 4,0 & 42,5 & 25,0 & 57,5 & 75,0 & 13,1 & 3,3 & 24,9 & 7,9 & & \\
\hline
\end{tabular}

Table 2. Health Expenditure in West Africa.

\begin{tabular}{|c|c|c|c|c|c|c|c|c|c|c|c|c|}
\hline \multirow{3}{*}{$\begin{array}{l}\text { WHO } \\
\text { states } \\
\text { members }\end{array}$} & \multicolumn{12}{|c|}{ Ratios of health spending in Sub-Saharan Africa } \\
\hline & \multicolumn{2}{|c|}{$\begin{array}{l}\text { Global } \\
\text { health } \\
\text { expenditures } \\
\text { (GHE) } \\
\text { (as \% } \\
\text { of GDP) }\end{array}$} & \multicolumn{2}{|c|}{$\begin{array}{l}\text { Spending of } \\
\text { public heath } \\
\text { administrations } \\
\text { (PHA) } \\
\text { (as \% } \\
\text { of GHE) }\end{array}$} & \multicolumn{2}{|c|}{$\begin{array}{l}\text { Private } \\
\text { health } \\
\text { expenditures } \\
\text { (as \% } \\
\text { of GHE) }\end{array}$} & \multicolumn{2}{|c|}{\begin{tabular}{|l|}
$\begin{array}{l}\text { Spending } \\
\text { of PHA }\end{array}$ \\
(as \% \\
of global \\
expenditure \\
of Public \\
Administration
\end{tabular}} & \multicolumn{2}{|c|}{$\begin{array}{l}\text { External } \\
\text { health } \\
\text { financing } \\
\text { (as \% } \\
\text { of GHE) }\end{array}$} & \multicolumn{2}{|c|}{$\begin{array}{l}\text { Social } \\
\text { security } \\
\text { health } \\
\text { spending } \\
\text { (as \% } \\
\text { of PHA) }\end{array}$} \\
\hline & 2000 & 2010 & 2000 & 2010 & 2000 & 2010 & 2000 & 2010 & 2000 & 2010 & 2000 & 2010 \\
\hline Bénin & 1,9 & 4,3 & 99,9 & 51,2 & 0,1 & 48,8 & 10,0 & 10,5 & 38,5 & 32,8 & 0,5 & 0,4 \\
\hline Burkina Faso & 5,1 & 7,4 & 39,6 & 55,4 & 60,4 & 44,6 & 8,8 & 15,7 & 13,9 & 36,1 & 0,8 & 0,4 \\
\hline Botswana & 4,7 & 5,1 & 62,2 & 64,5 & 37,8 & 35,5 & 7,3 & 8,7 & 0,5 & 8,0 & $\ldots$ & $\ldots$ \\
\hline Cap-Vert & 4,8 & 2,3 & 73,3 & 49,1 & 26,7 & 50,9 & 9,9 & 2,5 & 13,0 & 19,5 & 34,9 & 87,3 \\
\hline Côte d'Ivoire & 1,4 & 6,2 & 94,9 & 24,5 & 5,1 & 75,5 & 7,2 & 6,8 & 19,4 & 8,3 & $\ldots$ & $\ldots$ \\
\hline Gambie & 3,6 & 4,4 & 34,2 & 56,1 & 65,8 & 43,9 & 10,4 & 11,3 & 19,1 & 39,2 & 0 & 0 \\
\hline Ghana & 4,7 & 5,2 & 48,7 & 58,2 & 51,3 & 41,8 & 8,3 & 12,1 & 14,5 & 16,5 & 0 & 25,2 \\
\hline Guinée & 5,7 & 6,2 & 18,7 & 32,5 & 81,3 & 67,5 & 6,4 & 6,8 & 13,4 & 26,7 & 1,1 & 4,5 \\
\hline \begin{tabular}{|l} 
Guinée- \\
Bissau
\end{tabular} & 4,9 & 7,0 & 10,5 & 33,1 & 89,5 & 66,9 & 2,3 & 11,1 & 30,0 & 28,5 & 5,4 & 1,1 \\
\hline Libéria & 5,9 & 16,4 & 24,5 & 19,0 & 75,5 & 81,0 & 6,7 & 11,1 & 9,2 & 42,4 & 0 & 0 \\
\hline Mali & 6,0 & 6,5 & 29,2 & 43,5 & 70,8 & 56,5 & 7,5 & 12,3 & 8,2 & 22,2 & 1,8 & 0,7 \\
\hline Niger & 3,4 & 4,8 & 44,5 & 49,2 & 55,5 & 50,8 & 8,4 & 11,1 & 40,4 & 32,7 & 3,3 & 1,3 \\
\hline Nigeria & 4,6 & 5,4 & 33,5 & 31,5 & 66,5 & 68,5 & 4,2 & 5,7 & 16,2 & 8,7 & 0 & 0 \\
\hline Sénégal & 4,3 & 5,8 & 36,8 & 56,9 & 63,2 & 45,1 & 8,5 & 12,1 & 17,4 & 18,4 & 8,8 & 3,9 \\
\hline Sierra Leone & 17,5 & 20,8 & 22,6 & 15,3 & 77,4 & 84,7 & 14,2 & 11,7 & 5,5 & 26,8 & 0 & 0 \\
\hline Togo & 5,3 & 7,5 & 28,5 & 45,9 & 71,5 & 54,1 & 8,5 & 15,4 & 5,9 & 18,2 & 11,7 & 6,5 \\
\hline
\end{tabular}

Statistics Opt. \& Inform. Comput. Vol. 2, March 2014. 
Table 3. Health Expenditure in East Africa.

\begin{tabular}{|c|c|c|c|c|c|c|c|c|c|c|c|c|}
\hline \multirow{3}{*}{$\begin{array}{l}\text { WHO } \\
\text { states } \\
\text { members }\end{array}$} & \multicolumn{12}{|c|}{ Ratios of health spending in Sub-Saharan Africa } \\
\hline & \multicolumn{2}{|c|}{$\begin{array}{l}\text { Global } \\
\text { health } \\
\text { expenditures } \\
\text { (GHE) } \\
\text { (as \% } \\
\text { of GDP) }\end{array}$} & \multicolumn{2}{|c|}{$\begin{array}{l}\text { Spending of } \\
\text { public heath } \\
\text { administrations } \\
\text { (PHA) } \\
\text { (as \% } \\
\text { of GHE) }\end{array}$} & \multicolumn{2}{|c|}{$\begin{array}{l}\text { Private } \\
\text { health } \\
\text { expenditures } \\
\text { (as \% } \\
\text { of GHE) }\end{array}$} & \multicolumn{2}{|c|}{\begin{tabular}{|l|}
$\begin{array}{l}\text { Spending } \\
\text { of PHA }\end{array}$ \\
(as \% \\
of global \\
expenditure \\
of Public \\
Administration
\end{tabular}} & \multicolumn{2}{|c|}{$\begin{array}{l}\text { External } \\
\text { health } \\
\text { financing } \\
\text { (as \% } \\
\text { of GHE) }\end{array}$} & \multicolumn{2}{|c|}{$\begin{array}{l}\text { Social } \\
\text { security } \\
\text { health } \\
\text { spending } \\
\text { (as \% } \\
\text { of PHA) }\end{array}$} \\
\hline & 2000 & 2010 & 2000 & 2010 & 2000 & 2010 & 2000 & 2010 & 2000 & 2010 & 2000 & 2010 \\
\hline Burundi & 6,2 & 9,1 & 29,3 & 35,0 & 70,7 & 65,0 & 7,5 & 8,1 & 19,1 & 40,9 & 25,1 & 23,0 \\
\hline Djibouti & 4,0 & 7,9 & 99,2 & 68,5 & 0,8 & 31,5 & 12,0 & 14,1 & 47,7 & 22,1 & 11,3 & 9,6 \\
\hline Erythrée & 4,5 & 2,9 & 39,1 & 45,2 & 60,9 & 54,8 & 2,6 & 3,6 & 29,8 & 35,0 & 0 & 0 \\
\hline Ethiopie & 4,3 & 4,8 & 53,6 & 52,9 & 46,4 & 47,1 & 8,9 & 13,7 & 16,5 & 36,1 & 0 & 0 \\
\hline Kenya & 4,7 & 4,4 & 46,3 & 40,2 & 53,7 & 59,8 & 10,5 & 5,9 & 8,0 & 37,9 & 10,9 & 13,0 \\
\hline Maurice & 3,7 & 6,2 & 52,0 & 43,7 & 48,0 & 56,3 & 8,7 & 10,8 & 1,4 & 1,9 & $\ldots$ & $\ldots$ \\
\hline Ouganda & 6,6 & 9,2 & 26,8 & 23,1 & 73,2 & 76,9 & 7,3 & 10,8 & 28,3 & 27,6 & 0 & 0 \\
\hline Rwanda & 4,2 & 10,4 & 39,2 & 54,8 & 60,8 & 45,2 & 8,2 & 23,3 & 52,0 & 48,0 & 6,4 & 9,2 \\
\hline Seychelles & 4,8 & 3,3 & 82,7 & 91,9 & 17,3 & 8,1 & 7,3 & 9,3 & 4,3 & 4,2 & 5,0 & 1,1 \\
\hline Somalie & 2,4 & $\ldots$ & 44,8 & $\ldots$ & 55,2 & $\ldots$ & 4,2 & $\ldots$ & 40,1 & $\ldots$ & 0 & $\ldots$ \\
\hline Soudan & 3,3 & 7,2 & 25,8 & 27,6 & 74,2 & 72,4 & 7,6 & 10,3 & 4,5 & 2,9 & $\ldots$ & 11,1 \\
\hline Tanzanie & 3,4 & 7,2 & 43,4 & 39,2 & 56,6 & 60,8 & 10,2 & 11,1 & 27,8 & 39,6 & 0 & 4,5 \\
\hline Zambie & 5,7 & 6,0 & 51,3 & 60,8 & 48,7 & 39,2 & 9,4 & 16,0 & 17,8 & 43,7 & 0 & 0 \\
\hline
\end{tabular}

Table 4. Health Expenditure in Southern Africa.

\begin{tabular}{|c|c|c|c|c|c|c|c|c|c|c|c|c|}
\hline \multirow{3}{*}{$\begin{array}{l}\text { WHO } \\
\text { states } \\
\text { members }\end{array}$} & \multicolumn{12}{|c|}{ Ratios of health spending in Sub-Saharan Africa } \\
\hline & \multicolumn{2}{|c|}{$\begin{array}{l}\text { Global } \\
\text { health } \\
\text { expenditures } \\
\text { (GHE) } \\
\text { (as \% } \\
\text { of GDP) }\end{array}$} & \multicolumn{2}{|c|}{$\begin{array}{l}\text { Spending of } \\
\text { public heath } \\
\text { administrations } \\
\text { (PHA) } \\
\text { (as \% } \\
\text { of GHE) }\end{array}$} & \multicolumn{2}{|c|}{$\begin{array}{l}\text { Private } \\
\text { health } \\
\text { expenditures } \\
\text { (as \% } \\
\text { of GHE) }\end{array}$} & \multicolumn{2}{|c|}{$\begin{array}{l}\text { Spending } \\
\text { of PHA } \\
\text { (as \% } \\
\text { of global } \\
\text { expenditure } \\
\text { of Public } \\
\text { Administration }\end{array}$} & \multicolumn{2}{|c|}{$\begin{array}{l}\text { External } \\
\text { health } \\
\text { financing } \\
\text { (as \% } \\
\text { of GHE) }\end{array}$} & \multicolumn{2}{|c|}{$\begin{array}{l}\text { Social } \\
\text { security } \\
\text { health } \\
\text { spending } \\
\text { (as \% } \\
\text { of PHA) }\end{array}$} \\
\hline & 2000 & 2010 & 2000 & 2010 & 2000 & 2010 & 2000 & 2010 & 2000 & 2010 & 2000 & 2010 \\
\hline $\begin{array}{l}\text { Afrique } \\
\text { Sud }\end{array}$ & 8,1 & 8,7 & 42,3 & 46,6 & 57,7 & 56,4 & 10,9 & 12,4 & 0,3 & 2,2 & 3,3 & 2,9 \\
\hline Angola & 2,9 & 3,4 & 58,1 & 61,0 & 41,9 & 39,0 & 2,9 & 6,3 & 3,0 & 2,3 & 0 & 0 \\
\hline Comores & 3,6 & 5,3 & 42,1 & 57,2 & 57,9 & 42,8 & 9,3 & 13,1 & 20,5 & 15,3 & 0 & 0 \\
\hline Lesotho & 7,0 & 11,5 & 51,2 & 70,3 & 48,8 & 29,7 & 6,3 & 13,8 & 3,1 & 18,2 & 0 & 0 \\
\hline Madagascar & 3,7 & 3,6 & 66,5 & 58,1 & 33,5 & 41,9 & 15,5 & 13,5 & 20,1 & 9,5 & $\ldots$ & $\ldots$ \\
\hline Malawi & 3,0 & 8,4 & 91,2 & 74,2 & 8,8 & 25,8 & 9,0 & 18,5 & 53,4 & 58,1 & 0 & 0 \\
\hline Mozambique & 6,2 & 6,3 & 70,0 & 52,8 & 30,0 & 47,2 & 17,0 & 10,4 & 25,3 & 62,2 & 0,3 & 20,3 \\
\hline Maurice & 3,7 & 5,6 & 52,0 & 37,1 & 48,0 & 62,9 & 8,7 & 8,3 & 1,4 & 1,6 & 0 & 0 \\
\hline Mauritanie & 6,0 & 6,1 & 66,5 & 66,0 & 33,5 & 34,0 & 12,9 & 13,1 & 11,2 & 7,4 & 8,7 & 8,5 \\
\hline Namibie & 6,1 & 5,5 & 68,9 & 58,0 & 31,1 & 42,0 & 6,9 & 6,5 & 3,8 & 25,5 & 1,8 & 2,7 \\
\hline Swaziland & 5,3 & 7,8 & 56,3 & 71,1 & 43,7 & 28,9 & 10,5 & 13,7 & 5,8 & 14,4 & 0 & 0 \\
\hline Zimbabwe & & $\ldots$ & ... & & & & & & & & & \\
\hline
\end{tabular}

Source: Analysis of the 2013 Report of the WHO health statistics.

Furthermore, only $10.63 \%$ (5 of 47 countries) fulfilled at the Abuja commitments to allocate at least $15 \%$ of their budgets to health. This is Rwanda, Malawi, Zambia and Burkina Faso and Togo. In addition, many efforts are expected in most countries. Thus, $38 \%$ (18 out of 47 countries) still spend less than $10 \%$ of their budgets to health, while $51 \%$ ( 24 out of 47 countries) currently allocate between 10 and $14 \%$ of their budgets to health. Thus, for the Abuja commitment is respected by African States, other sources of funding are essential. Map1 below gives the distribution of the percentage of the budget allocated to health by African countries. 
Map 1: Budget allocated to health by African countries.
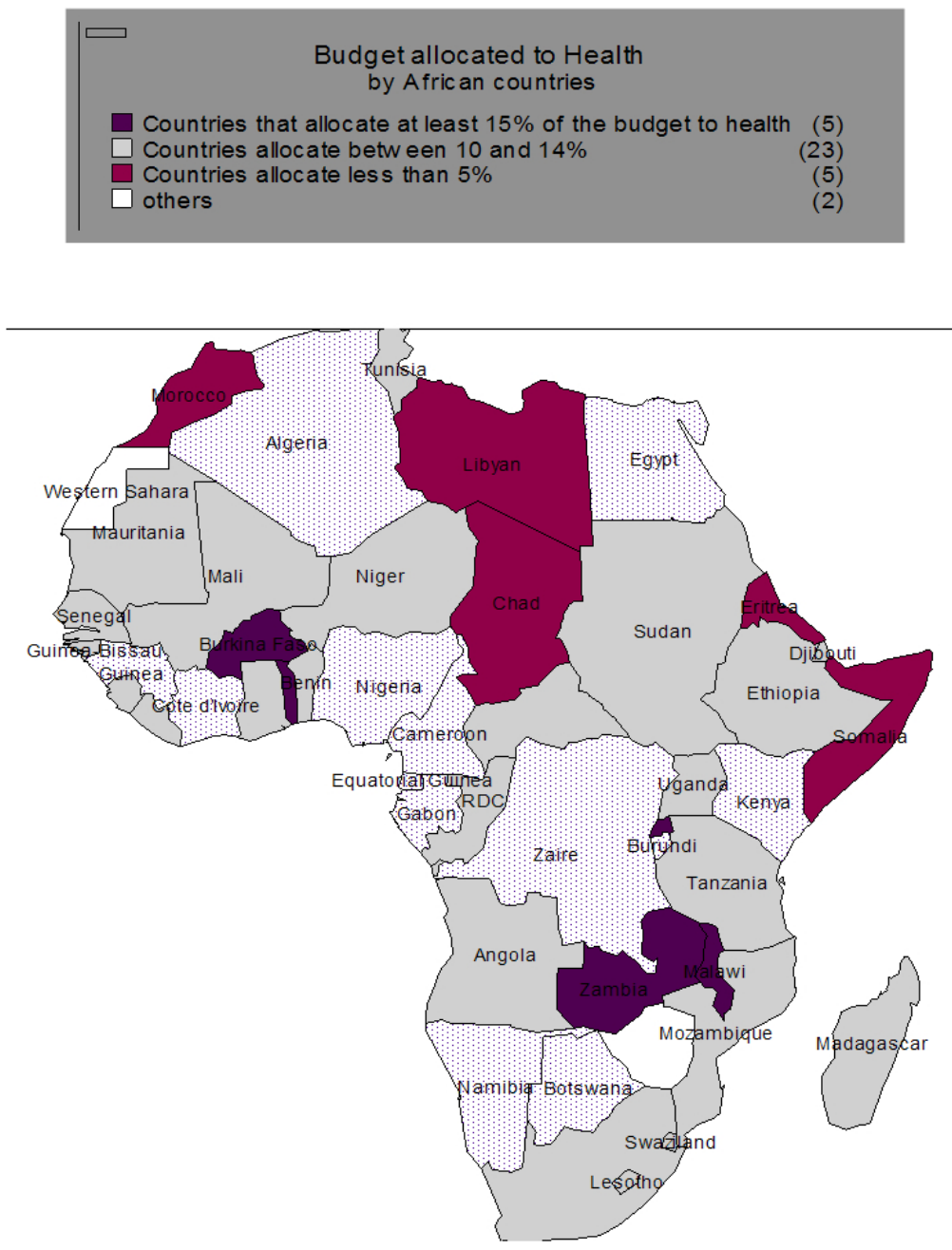

Source: Analysis of data from the 2013 report of the WHO World Health Statistics using MapInfo software. 
Graphic 2: Private Health Expenditure SSA countries between 60 and $70 \%$ of GDP.

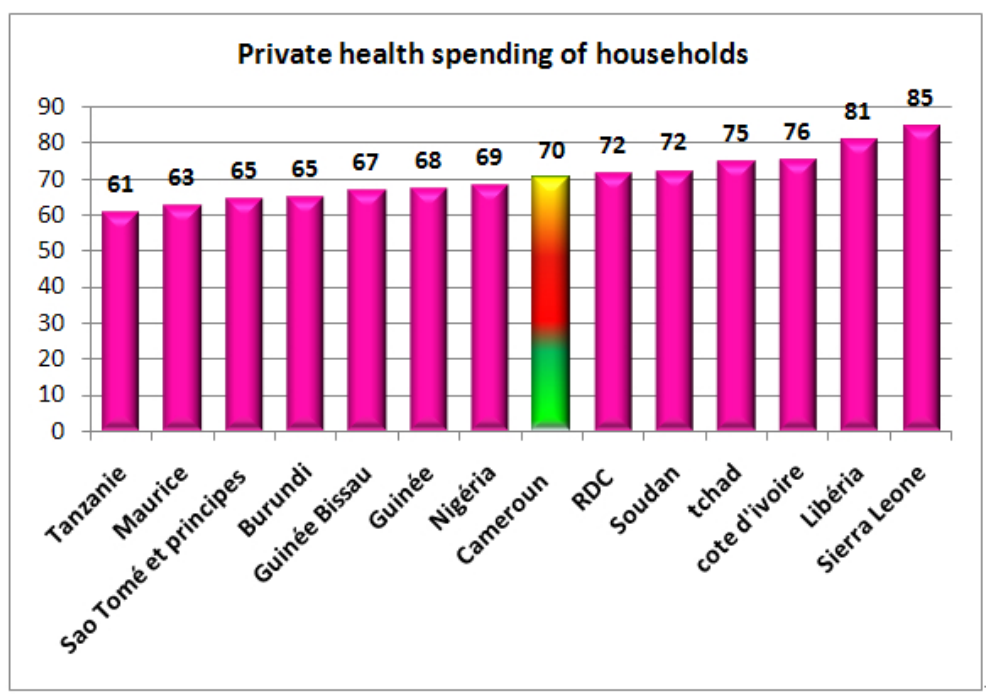

Source: Analysis of data from the 2013 report of the WHO World health statistics.

\section{Methodology}

\subsection{Data source*}

The frame used consists of enumeration areas (EAs) of the last census of population and housing Census (PHC 2005). In each borough or district, the urban EAs are numbered from 001 to 699 and those in rural areas from 700 to 999. A recovery rate of raw data on the population of 1.2 was used. First degree in each stratum, is derived enumeration areas (EAs) in proportion to their size to account for remaining differences between these sizes, the second stage, a sample of households is drawn in each selected first-degree ZD. Thus, in all 12 survey areas, 12609 households were selected in 742 ZD, a staff of 12 households per EA Douala / Yaound and 18 in the rest of the country. Purchases and acquisitions were recorded daily for 15 days in each urban household and two passages in rural households covering 10 days should be supplemented by statements of historical

\footnotetext{
*The general methodology in the context of the third national survey on poverty reality by the National Institute of Statistics in 2007is detailed in the report of the investigation and downloaded from the website of theINSCameroon. This is the data from this survey will be used as the basis for our analysis.
} 
costs. The investigation lasted three months, in order to take into account seasonal fluctuations.

\subsection{Macroeconomic approach to overall expenditure}

The macroeconomic approach used here is that the overall expenditure of Keynes*, that "the level of real income (ignoring the price) is the main determinant of the overall expenditure cause." To this end, the overall expenditure (AE) is the sum of what households plan to buy (or consumption $\mathrm{C}$ ), and that the companies plan to consume in the form of capital (or investment I): $\mathrm{AE}=\mathrm{C}+\mathrm{I}$. Thus, the desire to use a proportion of income (Y) for consumption (C) is called the average propensity to consume $(\mathrm{APC})$ : $\mathrm{APC}=\mathrm{C} / \mathrm{Y}$. As incomes rise, the average propensity to consume decreases. Indeed, one can observe this phenomenon among affluent individuals who spend a smaller share of their income on consumption than do the poorest (the latter may in fact be obliged to receive money from others). The marginal propensity to consume (MPC) is the proportion of additional consumption (dC) which will be added in an increase in income (dY): $\mathrm{MPC}=\mathrm{dC} / \mathrm{dY}$.

The main assumption in this study is as follows: "The level of income determines the overall health care spending."

To verify the said assumption, we use the multivariate analysis methods, using SPSS (Statistical Package Social Sciences) software on Windows using statistical techniques of regression of variance (ANOVA one-factor), and the Multiple Correspondence Factor Analysis (MCA). This will allow us to highlight the change in weight of health expenditures on household income. The data to be used will be those of the third survey on the living conditions of the population and the poverty profile in Cameroon, conducted in 2007 (ECAM III).

\section{Analysis of Weight Health Costs on Household Income}

\subsection{Macroeconomic approach to overall expenditure}

The average annual income of Cameroonian society has increased between 1996 and 2001, from 243,240.44 FCFA in 1996 to 294,403.41 in 2001, an increase of 21\% (ECAM 1996 and 2001), before moving to 659,376 FCFA in 2007. Despite this increase in income, however, there many inequalities between income distributions at the national level. The Gini coefficient rose from 0.406 in 1996 to

\footnotetext{
${ }^{*}$ The main approach presented here is the use of Keynes to propose a solution for excessive periods of unemployment(ied.Duringrecession) aims. This solution is related to the idea that employment depends on what companies must produce while the production level depends on what households and businesses plan to buy. This is what Keynes called the overall expense.
} 
0.408 in 2001, a positive variation of 0.002 , indicating the increasing inequality in Cameroon. To account for the distribution of income accurately, we calculate the distribution of Theil index, Gini and Hoover in 2007.

\subsubsection{Theil index}

The Theil index $\left(T_{i}\right)$ is a measure of inequality based on the Shannon entropy :*

- An index of 0 represents absolute equality;

- An index of 0.5 indicates inequality represented by a society where $74 \%$ of people have $26 \%$ resources and $26 \%$ of individuals $74 \%$ of resources;

- An index of lindicates inequality represented by a society in which $82.4 \%$ of individuals were $17.6 \%$ and $17.6 \%$ of there sources individuals have $82.4 \%$ of the resources.

We calculated the Theil index from the following formula:

$$
T=\ln \left(\frac{\text { Atotal }}{\text { Etotal }}-\frac{\sum_{i=0}^{N} \operatorname{Eiln}\left(\frac{A i}{E i}\right)}{\text { Etotal }}\right) .
$$

- N: Number of quartiles;

- Ei: Resources for the quartile i ;

- Ai:effectiveinquartilei ;

- Etotal: resources for all quartiles in a society(a nation, etc...);

- Atotal: size of the company(the nation, etc..).

The Theil index obtained from this formula is $\mathrm{T} i=1$. Wethusconcludethat the Cameroonian society is represented by theinequalitywhere $82.4 \%$ of individuals have $17.6 \%$ and $17.6 \%$ of there sources individuals have $82.4 \%$ of the resources.

\subsubsection{The Gini Index}

The Gini coefficient $(\mathrm{G})$ in turn is a measure of the degree of inequality of income distribution in a given society, developed by the Italian statistician Corrado Gini. The Gini coefficient is a number ranging from 0 to 1 , where 0 means perfect equality (everyone has the same income) and 1 corresponds to perfect inequality (one person has all the income, others have nothing Extreme cases of master and slaves).

We calculated the coefficient from the following formula:

$$
G=1-\sum_{i=0}^{p-1}\left(\left(n_{i}+1\right) / n\right) \times\left(\beta_{i}+\left(\beta_{i}+1\right)\right)
$$

*The Shannon entropy, due to Claude Shannon (circa 1948) is a mathematical function that intuitively corresponds to the amount of information contained in or supplied by a source of information. This source can be written in a particular language text, an electrical signal or any computer file (collection of bytes). Is a fundamental discrete $\Omega=\left\{\omega_{i}, i \in I\right\}$ and $\mathrm{P}$ is a probability measure on $(\Omega, \mathrm{P}(\Omega))$, Shannon entropy is defined by $I(P)=-\sum_{i \in I} p_{i} \log \left(p_{i}\right)$ and $p_{i}=P\left(\left\{\omega_{i}\right\}\right)$. In addition, entropy is combinatorial version of discrete probabilities or by continuous probability. 
Where $\mathrm{k}$ is from 1 to $\mathrm{n}$,we calculate: $\alpha_{k}=\left(n_{1}+n_{2}+\cdots+n_{k}\right) / n$ and $k=$ $\beta\left(n_{1} \times x_{1}+n_{2} \times x_{2}+\cdots+n_{k} \times x_{k} \cdots\right) / m$

We always have $\alpha_{p}=\beta_{p}=1$. For convenience we take $\alpha_{0}=\beta_{0}=0 . \alpha_{k}$ is the percentage of individuals having a value of less than or equal to $\mathrm{x}_{k}$ character: these individuals have a fraction of the total mass equal to $\beta_{k}$. We can also say that $\beta_{k}$ is the mass (in \%) owned by the $\alpha$ first $\mathrm{k}$ individuals (in \%), these are sorted by increasing value of the character.

By applying the above formula, we obtain the value of $\mathrm{G}=0.712$ in 2007 , an increase of 0.3 between 2001 and 2007. This result shows that income inequalities are quite high in Cameroon.

\subsubsection{Index Hoover}

Hoover index $(\mathrm{H})$ is the simplest of all indices measuring income inequality. It is equal to the income portion of the population that should be redistributed. This is the portion that must be taken to the richest part of the population (above average income) and given to the poorest (below average income) part so that there is perfect equality (everyone has to income, average income). We used the following formula to calculate this index:

$$
\mathrm{H}=\frac{1}{2} \int_{i=1}^{N}\left|\frac{E i}{\text { Etotal }}-\frac{A i}{\text { Atotal }}\right|
$$

1. N: Number of quartiles;

2. Ei: Resources for the quartile i ;

3. Ai: effective in quartile $\mathrm{i}$;

4. Etotal: resources for all quartiles in a society (a nation, etc...)

5. Atotal: size of the company (the nation, etc...).

- Advantage: The index is between 0 (uniform distribution) and 1 (maximum concentration). Note that the value 1 could only be achieved if we had an infinite number of individuals possessing nothing and a person having any;

- Disadvantages: The index does not provide information on the structure of inequalities ( 2 different income groups or one person rich and many poor people).

The Hoover index is generally used in applications related to socio-economic classes and health. But this index does not measure inequality within the richest or poorest parts. This is why we can to prefer the Gini coefficient, which is based on the Lorenz curve. By applying the above formula, we find $\mathrm{H}=0.698$. Once again, the result shows that income inequality is quite important in 2007 in Cameroon. These results can be illustrated by the Lorenz curve below:

The above results are the fruit of a Cameroonian economy slowed during the period between 1997 and 2005, when real GDP growth slowed from 5.31\% to $2.3 \%$ (INS, 2010). This slowdown is due to the deterioration of the trade balance, the sluggish international economic environment and worsening fiscal constraints due to the combined effects of the global economic and financial crisis, the food 


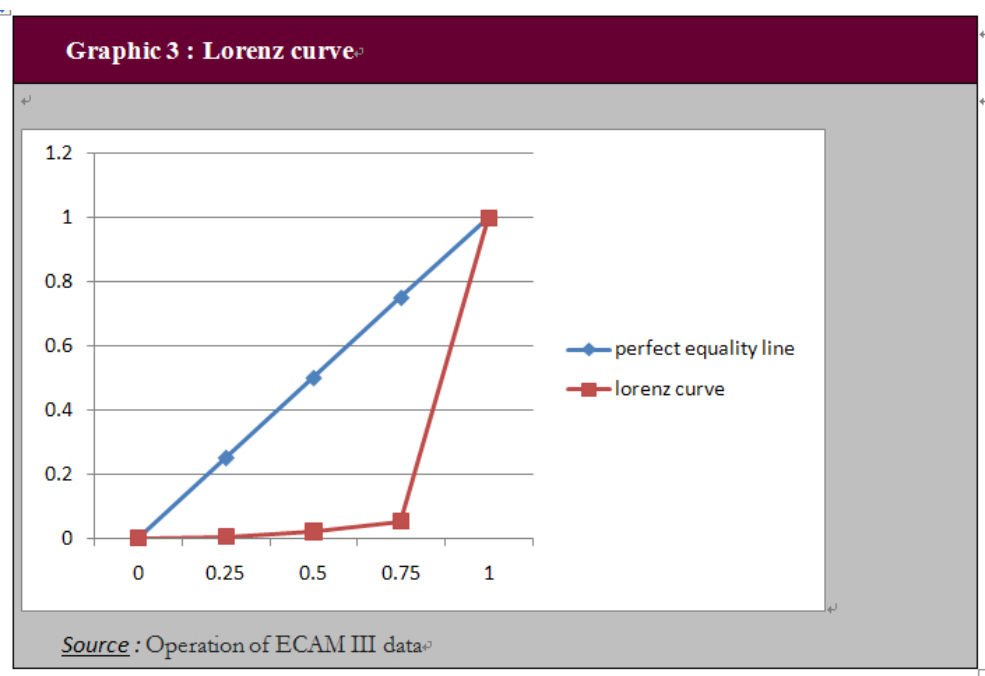

crisis and the energy deficit. Figure 4 below shows the trend in GDP growth in Cameroon.

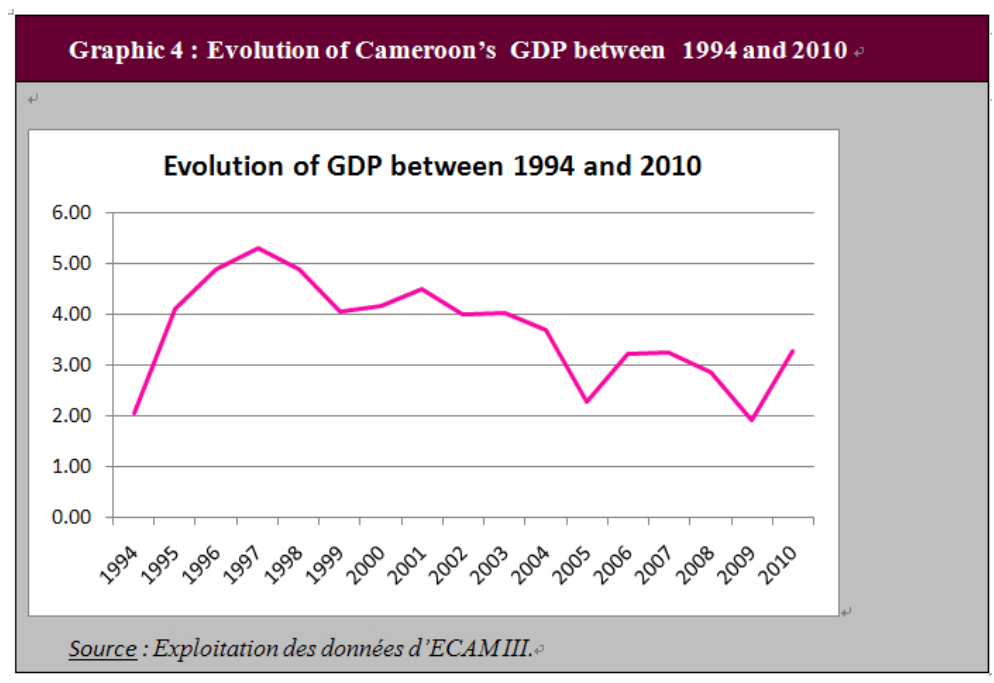

Despite reaching the completion point of the HIPC initiative in 2006 and the signing of the C2D with France, unemployment and underemployment remain very important in Cameroon, especially among young people. The result is a general discontent of youth that has little hope of social advancement. This led to riots in Cameroon in February 2008, reflecting the discontent of people facing 
hunger and rising fuel prices and that of commodities.

Also, the government has taken emergency measures to boost the agricultural sector, including the production prioritized such as maize, rice, cassava, potato, oil palm and plantain.

\subsection{Marginal and average propensity of the total medical consumption}

\subsubsection{Marginal propensity Medical Consumption}

As we defined in the methodology section reserved for the marginal propensity to consume (MPC) is the proportion of additional consumption (dC) which will be added in an increase in income $(\mathrm{dY}): \mathrm{MPC}=\mathrm{dC} / \mathrm{dY}$. We calculated between the two surveys that took place in 2001 and 2007. The average monthly income obtained from the frequency distribution amounted to 54,948 FCFA in 2007 against 37,000 in 2001, the average annual health expenditure to 12,775 FCFA in 2007, against 22,000 FCFA in 2001, according to reports General surveys in 2001 and 2007.

Thus, $\mathrm{MPC}=(12775-22000) /(54948-37000)=-9225 / 17948=-0.5$. This result shows that consumption decreased between 2001 and 2007, but at a slower pace compared to the increase in income. The value of the elasticity obtained by the English law is as follows:

$$
\begin{aligned}
& \varepsilon=\Delta \mathrm{C} / \mathrm{C} / \Delta \mathrm{R} / \mathrm{R}=\left(\left(\mathrm{C}_{2}-\mathrm{C}_{1}\right) / \mathrm{C}_{1}\right) /\left(\left(\mathrm{R}_{2}-\mathrm{R}_{1}\right) / \mathrm{R}_{1}\right. \\
& \varepsilon=((12775-22000) / 12775) /((54948-37000) / 54948=-0.86
\end{aligned}
$$

We get $\varepsilon=-0.86<0$. We find ourselves in a situation of inferior goods, that is to say, the demand decreases when income increases.

\subsubsection{Average propensity of Total Medical Consumption}

As we noted earlier, $\mathrm{APC}=\mathrm{C} / \mathrm{Y}$. We created this indicator using the analysis software SPSS data. To this end, we excluded households with zero health expenditure (20\% of households surveyed) to avoid overstaffing for the first quartile of health expenditure because only individuals who spent feel the weight of health spending. Also, to avoid bias related to the measurement of health care spending, we selected only the expenses of the household head, since it supports most of the household expenses. In addition, we obtained the following results: among the 11,391 households surveyed, 9,018 households or $80 \%$ actually spent on health in 2007 . Of these 9,018 households, $32.2 \%$ spent less than half of their 
income on health, $16.3 \%$ in turn spent more than half of their income on health, and finally, $51.5 \%$ of households spent most of their total income on health.

Table 5.Average Propensity of total Medical Consumption by region.

\begin{tabular}{|l|l|l|l|}
\hline Regions & \multicolumn{4}{|l|}{$\begin{array}{l}\text { Average Propensity of medical consumption of } \\
\text { households by region (\%) }\end{array}$} \\
\hline & $\begin{array}{l}\text { Less than half } \\
\text { of income }\end{array}$ & $\begin{array}{l}\text { More than half } \\
\text { of income }\end{array}$ & $\begin{array}{l}\text { Over the } \\
\text { entire income }\end{array}$ \\
\hline Adamaoua & 48 & 18,7 & 33,3 \\
\hline Far-north & 32,6 & 14,7 & 52,7 \\
\hline North & 33,2 & 16,9 & 49,9 \\
\hline East & 33,1 & 19 & 47,9 \\
\hline Centre & 33,6 & 15,8 & 50,7 \\
\hline Littoral & 31,6 & 16,4 & 52 \\
\hline North-West & 21,6 & 12,2 & 66,2 \\
\hline West & 20,4 & 16,8 & 62,7 \\
\hline South & 37,6 & 18,8 & 43,6 \\
\hline South-West & 27,9 & 16,7 & 55,4 \\
\hline National & $\mathbf{3 1 , 9 6}$ & $\mathbf{1 6 , 6}$ & $\mathbf{5 1 , 4 4}$ \\
\hline
\end{tabular}

Table 6. Weight of health expenditures by region.

\begin{tabular}{|l|l|l|l|}
\hline Regions & \multicolumn{3}{|l|}{ Health expenditures by income for any region (\%) } \\
\hline & $\begin{array}{l}\text { Average } \\
\text { monthly } \\
\text { income by } \\
\text { region FCFA }\end{array}$ & $\begin{array}{l}\text { Average health } \\
\text { expenditure } \\
\text { by region }\end{array}$ & $\begin{array}{l}\text { Average } \\
\text { propensity } \\
\text { by region }\end{array}$ \\
\hline Adamaoua & 72192,20 & 47272,20 & 0,65 \\
\hline Far-north & 52995,60 & 44064,93 & 0,83 \\
\hline North & 48961,20 & 53438,69 & 1,09 \\
\hline East & 34687,00 & 42778,16 & 1,23 \\
\hline Centre & 51229,28 & 66961,02 & 1,31 \\
\hline Littoral & 41345,03 & 55135,62 & 1,34 \\
\hline North-West & 31943,82 & 52571,87 & 1,65 \\
\hline West & 43827,30 & 68359,52 & 1,56 \\
\hline South & 76352,24 & 59523,65 & 0,78 \\
\hline South-West & 51387,20 & 64011,14 & 1,25 \\
\hline National & $\mathbf{5 0 4 9 2 , 0 8}$ & $\mathbf{5 5 4 1 1 , 6 8}$ & $\mathbf{1 , 0 9 7}$ \\
\hline
\end{tabular}

Source: Operation of ECAM III data

Spending overall health national level amounted to FCFA 711,343,126 while the total annual income of FCFA 565,795,940, representing an annual average propensity of the total medical consumption of 1.25 . This result shows that the 
Cameroonian population spends more than all of the income to health. The tables below summarize the situation.

From Table 5, so we see that the weight of health care spending to income is $(16.3+51.5=68 \%)$. This result reflects the fact that Cameroon is a country where the problem of the rational use of resources. In addition, incentives are not sufficiently relevant to the optimization of the efficiency and cost moderation. To this end, the development of mechanisms that promote the best value for money for medical care is needed. In the same vein, the result is in line with the WHO data according to which the private health expenditures represent $70.4 \%$ of total government expenditure in Cameroon. These results are also shown in Map 2 below, where seven out of 10 regions (70\%) bear the weight of health care spending:

Map 2: Health expenditure by region in Cameroon.

Poids des dépenses de santé suivant la Region

$\square$ plus de la totalite du revenu (6)

totalite du revenu (1)

moins de la totalite du revenu (3)

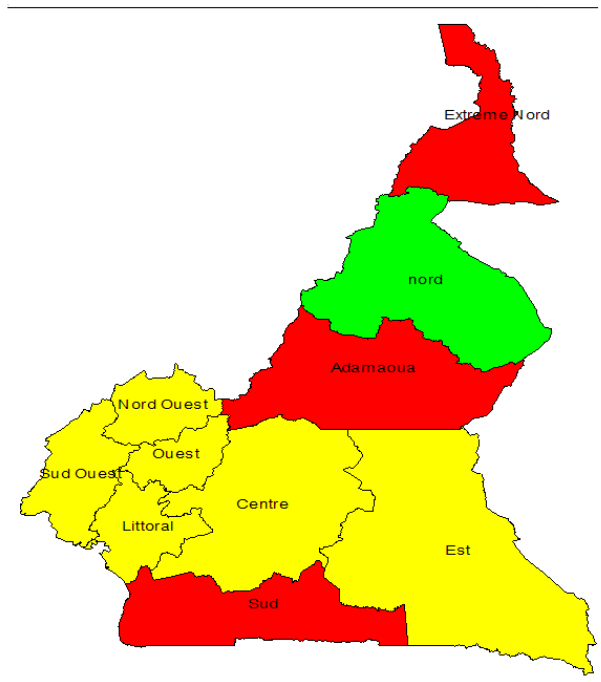

Source: Analysis of data from the national survey ECAM 2007 on poverty and living conditions of households, using MapInfo software. 


\section{Analysis of the correlation between overall health expenditure and income, using the one-way ANOVA.}

Analysis of variance is to determine the average, which differs most from the other or average torques which oppose the most between a dependent variable and one or more independent variables.

This analysis will allow us to determine the different behavior in terms of consumption expenditure according to income groups (quartiles of income) households.

We start from the hypothesis $\mathrm{H} 0$ according to which "the average health expenditure observed in the various income groups are all equal" and wants to confront the alternative that "the average health expenditure observed in various groups are not all equal "(hypothesis H1). This calculates the statistical Fisher observed (Fobservé) as compared with the theoretical Fisher (Fth?orique). For this purpose, if:

1. If Fobservé $>$ Fthéorique then $\mathrm{H} 0$ is rejected at the risk of error $\alpha$. In other words, if the p-value $<\alpha$ then $\mathrm{H} 1$ is accepted and the averages are statistically different;

2. If Fobservé $\leq$ Fthéorique hypothesis $\mathrm{H} 0$ is accepted: $\mathrm{p}$-value $>\alpha$ then $\mathrm{H} 1$ is rejected and the averages are statistically equal.

The results of the ANOVA model led us to the following conclusions:

Health expenditures vary from one income class to another and so this growth (Health expenditures increases with income level); The Fisher statistic for a $95 \%$ chance is Fobservé $(3,10293)=146>$ Fthéorique $(3,10293)=2.61(\mathrm{P}$-value $=$ $0.00<5 \%$ ).

We can therefore reject the hypothesis $\mathrm{H} 0$ (and accept H1). It concludes that the average income quartiles health expenditures are equal. The graph below shows us well that "more income increases on average, households spend on health." 
Graphic 4: Average income by expenditure quartile Health.

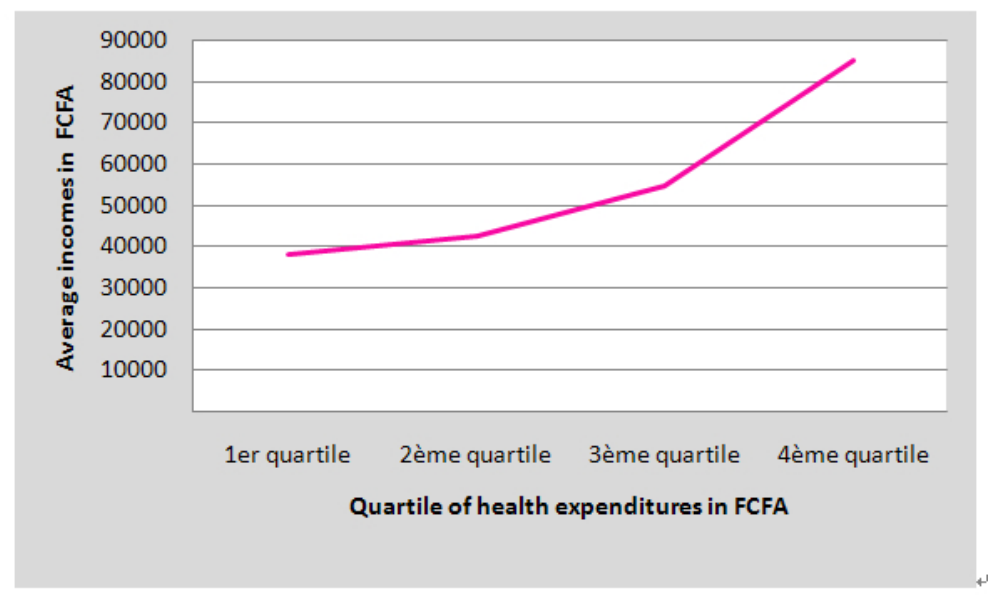

\section{Source: Operation of ECAM III data}

The diagram below illustrates the theory of Duesenberry (demonstration effect), that economic agents of a particular social group tend to imitate the consumption of high-income social group by demonstrating their social status.

\section{Multiple correspondence analysis (MCA) and the profile of the population according to health spending}

Factor analysis methods* include search subspaces of small dimensions that best fit the scatter of individuals and the scatterplot of variables. The proximities measured in these subspaces should best reflect the actual proximity. The representation space obtained is called factorial space.

The methods differ depending on the nature of the analyzed variables can be continuous variables, categorical variables or categories in the case of contingency tables. The lines can be individuals or groups.

To build our analytical model, we used seven variables:

1. Continuous-variables: household income, health expenditure;

\footnotetext{
* Formorein formation, pleasere fertotheuser' sworkLebart, MorineauandPiron(1995).
} 
2. Illustrative-nominal variables: the weight of health expenditure in household income;

3. Nominal variables: the age of the household head group, his place of residence, socio-occupational category, level of education and standard of living of the household.

Focused on the choice of these variables is justified by the fact that these are the main determinants of health expenditure and well-being of the population. Pathway following model has guided our choice (figure 1).

Three criteria allowed us to retain five factorial axes: (i) the method of Cattle (method or the elbow), which helps to retain the number of axes that lie after breaking information, (ii ) Kaiser method, which holds the number of axes in the axis value of the last question is greater than the average of the eigenvalues ??(iii) the method of the cumulative percentage of inertia (which holds the number of axes as the last line reveals considered at least $60 \%$ of the inertia of the point cloud. Based on these three criteria, we finally selected two factorial axes (axis 1 and axis2) among the five because they reflected the maximum information.

Figure 1: The Pathway model of the Commission on Social Determinants (CDSS)

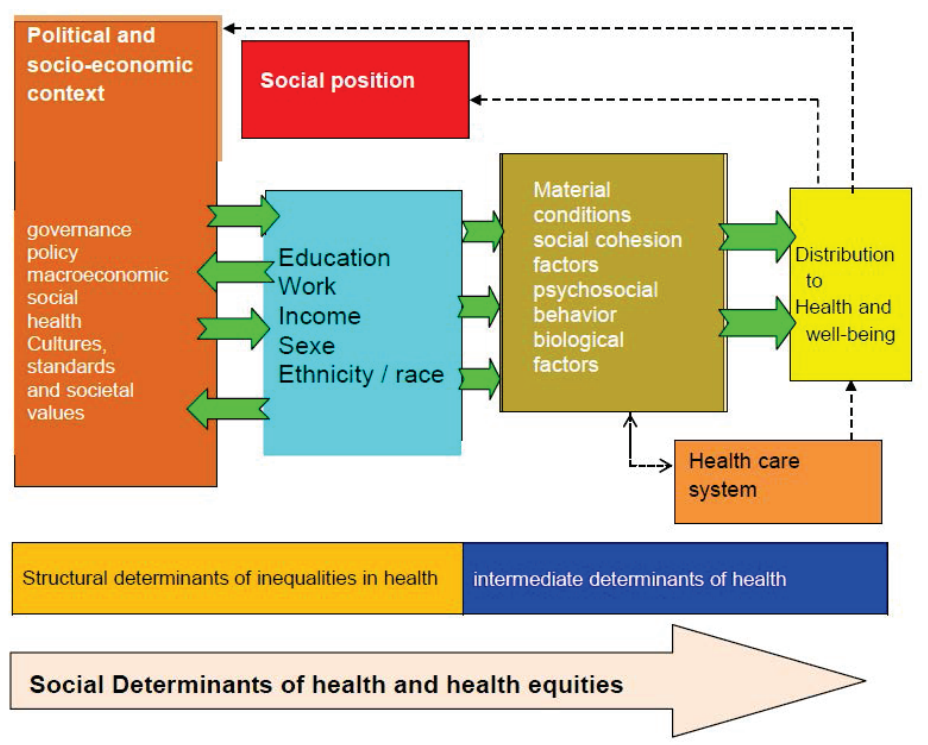

Source: Solar and Irwin, WHO, 2007 and 2010 
The data analysis allowed us to identify two major patterns of health expenditure of households, the following sociodemographic variables shown in Table 7 below:

Table 7: Profile of health expenditures according to certain sociodemographic variables

\begin{tabular}{|l|l|}
\hline $\begin{array}{l}\mathbf{1}^{\text {st }} \text { Profile: Heads of households } \\
\text { who spend less than half of income } \\
\text { on health }\end{array}$ & $\begin{array}{l}\mathbf{2}^{\text {nd }} \text { profile : : Heads of households } \\
\text { who spend more than the entire } \\
\text { income on health }\end{array}$ \\
\hline Age : under 30 years old & Age : 60 years old and over \\
\hline $\begin{array}{l}\text { Level of education: Secondary and } \\
\text { Higher }\end{array}$ & Level of education ; out of school \\
\hline Place of residence: urban & Milieu de résidence : rural \\
\hline $\begin{array}{l}\text { Occupational category: } \\
\text { non-agricultural informal, formal } \\
\text { private and public sector }\end{array}$ & $\begin{array}{l}\text { Occupational Category : agricultural } \\
\text { informal }\end{array}$ \\
\hline Income: 3rd and 4th quartile & Income : $1^{\text {st }}$ quartile \\
\hline
\end{tabular}

Source: Operation of ECAM III data

We obtain a classical result, characteristic of sub-Saharan Africa, where we have one hand, a poor aging population in rural areas facing demographic vulnerabilities, as opposed to the other a young population residing in urban, educated generally working in the public, private and non-agricultural informal. This result illustrates somehow "theory of urban bias*."

The graphical representation of Factor1 and Factor2 obtained from the SPAD software in Multiple Correspondence Analysis (MCA) is given below:

\section{General Conclusion}

The issue of the proper functioning of the health system is to improve the quality of life of individuals, families and communities. It is for this reason that the performance of the health system should be the top priorities for government action (Hamidou Baba et al., 2012). However, the health systems of the Member States of the WHO African Region States are struggling to effectively perform their duties because of their weakness and fragmentation. Weak health systems is explained by a number of factors, namely: deficiencies

*According to Lipton (1976) cited by Cris Beauchemin (1993), "Cities play a negative role in the development because they absorb all the resources at the expense of rural areas and the agricultural sector." 
in planning and forecasting, the lack of human, financial and material resources, the lack of data in order to inform informed decision making; gaps in institutional processes and weaknesses of performance monitoring and impact of interventions.

Graphic 5: Factorial consisting axe1 and axis2.

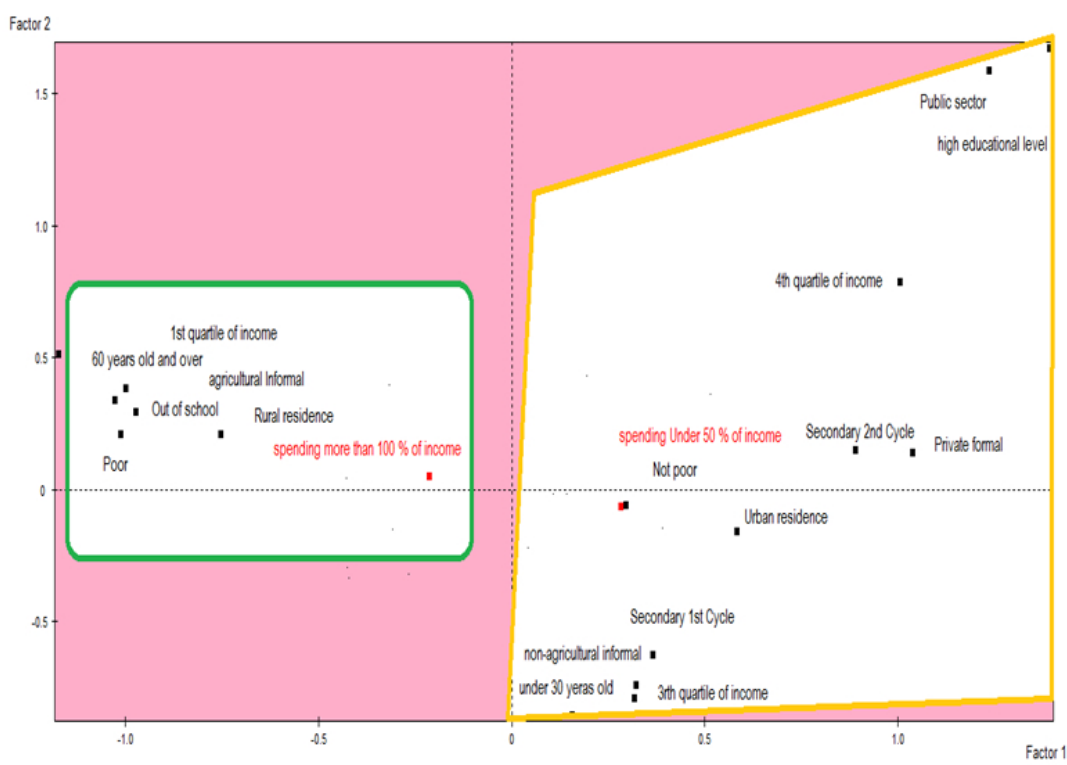

\section{Source: Analysis of data from ECAM III}

In Cameroon, the expense of overall health at the national level is high, or 711 343126 FCFA, corresponding to an overall annual income of FCFA 565,795,940, representing an annual average propensity of the total medical consumption of 1.25. Cameroon's population spends more than all of the income to health. The marginal propensity to consumption is -0.5 , highlighting the reduction of medical consumption between 2001 and 2007, but at a slower pace compared to the increase in income. Despite the fact that demand decreases when income increases (elasticity coefficient $\varepsilon=-0.86$ ), Cameroon is found in a situation of inferior goods in health. "As income increases on average, households spend on health." The macroeconomic approach to the overall expense of Keynes, that "the level of real income (ignoring the price) is the main determinant of the overall expenditure" has been checked.

So we finally two profiles of households facing health spending: first, households with poor aging rural population who spend more than the total 
income on health, as opposed to the other households consisting of a young population residing in urban areas, educated, usually working in the public, private and non-agricultural informal spending less than half of income on health. This highlights the "theory of urban bias."

Strengthening health systems is therefore a prerequisite for any significant progress in health in the African Region and even the world. In this sense, the health system must be approached holistically and approached as a whole and not item by item. Without such a vision, most initiatives focus only on resources related to specific diseases or specific target groups, usually letting the components to account for organizational processes. But it is in these processes plays the structuring of the system, that is to say, the articulation of human and material resources, the functions of the various organs and their methods of cooperation.

\section{Recommendations}

Major reforms are needed to allow for adaptation of the organization of health systems in Africa so that they guarantee sustainable way health solidarity in 21 st century. To this end, we recommend:

\section{To the World Health Organization (WHO) members States,}

1. the exemption from social charges on salaries;

2. compliance with the Abuja commitments and launch studies traceability and impact to optimize the management of the budget allocated to health;

3. the acceleration of the operation of health insurance in the states where the need is still felt;

4. Awareness of how key contextual factors, including budgetary constraints, affect the ability of a country to achieve its policy objectives.

\section{REFERENCES}

1. Adam Leive, $\mathrm{Ke} \mathrm{Xu,} \mathrm{2008:} \mathrm{How} \mathrm{do} \mathrm{they} \mathrm{deal} \mathrm{with} \mathrm{household} \mathrm{health} \mathrm{expenditure} \mathrm{in} \mathrm{their} \mathrm{care:}$ empirical evidence from 15 African countries (WHO) Bulletin of the World Organization of the previous Volume Health, Volume 86, November, 817-908.

2. Hamidou Baba et al, 2012: "Strengthening health systems in the countries of the WHO African Region: Meeting the challenge"; . WHO Regional Office for Africa, Brazzaville, Corresponding Author Hamidou Baba-Moussa E-mail: babamoussaamidou@yahoo.com.

3. CISS 2010 Health solidarity in danger? Reflection of CISS (www.santesolidaireendanger.org).Commeyras, Ndo Merabet et al. 2005: Study of the determinants of accessibility and use of health care and medicine in Cameroon.

4. EPI, 2011: Complete Multi-Year Plan 2011-2015 Ministry of Health of Cameroon.

5. INSEE, 2013: National Institute of Statistics and Economic Studies of France: www.insee.fr / definitions and methods). 
6. INS, 2010: Data from the National Accounts of Cameroon.

7. IRDES, 2013: Institute for Research and Information in Health Economics (www.irdes.fr / definitions).

8. J. Chuma and T. Maina, 2012: Catastrophic health care Spending and impoverishment in Kenya, Chuma and Maina BMC Health Services Research 2012, http://www.biomedcentral.com/1472-6963/12/413; 9p.

9. Minea, 2011 What type of financing of productive public spending in developing countries and middle income? (Cerdi, UdA);

10. S. Ambapour, 2004: "Comparison of health systems in sub-Saharan Africa Technical efficiency: an application of the method of DEA", Working Paper, BAMSI, 31p.

11. Sieleunou, Keugounget Yumo, 2010: Health care financing in Cameroon: Trends analysis and overview of main challenges?

12. V. Richard, 2004: Financing of Health in Sub-Saharan Africa. Cost recovery, 4p. Trop Med 2004, 64: 337-340.

13. V. Albouy, E. BRETIN, N.CARNOT Mr Deprez, 2009: Health spending in France: Determinants and impact of aging in 2050.

14. WHO, 2004: Regional Committee for the Eastern Mediterranean September 2004 Fifty-first session;

15. WHO, 2008: "Funding Policy Health: A Guide for Policymakers," by Joseph Kutzin, "Memorandum on financing health division of health systems of countries," $34 \mathrm{p}$.

16. WHO 2013: World Health Statistics 2013, 172p.

17. WHO 2012: World Health Statistics 2012, 176p.

18. WHO 2011 Report on the global health. The financing of the health system: the path to universal coverage, $22 \mathrm{p}$.

19. WHO, 2011: "Bridging the Gap: From policy to action on the social determinants of health."

20. World Conference on Social Determinants of Health, Rio de Janeiro, 19-21 October 2011, $56 \mathrm{p}$. 